\title{
“There is No Home, Pig": Examining the Dilemma of Northeast Queer in Time of Covid-19
}

\author{
Lede E Miki Pohshna
}

Research Scholar, English Department, North-Eastern Hill University, Emailledeemiki@gmail.com, ORCID-https://orcid.org/oooo-0oo3-0434-9704

\begin{abstract}
While COVID-19 has unleashed waves of reverse-migration from the cities back to the hometowns due to economic and physical uncertainties that accompanied the pandemic, queer people from the North-Eastern Region of India choose to stay in the cities. Defying the reverse-migration trend, they choose the freedom that the city gives them over the prejudice of their hometown toward their sexuality. This paper will theorize how pandemic affects and at the same time affirms queer sexualities This paper will re-interpret metronormativity in the context of North-East queer people and will co-opt Judith Halberstam's theory while at the same time reworking it to fit the local context of queer North-East. Unlike Halberstam's theory that the metro offers a continuum of free existence to the queer people, this paper will examine certain queer narratives both online and through interviews in order to understand how the city offers not a "freer" existence ( in the sense that freedom is given and implied upon) but rather a relatively anonymous existence which allows them to live freely in anonymity but never silent. It will problematize the concept of home and space and how queer subjectivities are (un)formed depending upon certain variables that the home offers which eventually affects queer existence. This existence will then juxtapose with Kosofsky's "gesture of silence" of the home and the closet and in doing so, it will attempt to understand North East queer's preference for the danger of COVID 19 and the "insecurities" of the city over the "security" of home.
\end{abstract}

Keywords: Northeastern, Queer, Metronormativity, Reverse-Migration, COVID-19

When I contacted John Doe (name changed), whom I have known for a number of years now, he informed me that he isn't coming home despite the fact that lakhs of migrants are going back to their home state at the cost and hardship is enormous (Bhagat et al, 2020, p4). The pandemic COVID 19 has wreak havoc across all states of India and the migrants are the worst displace group of people.But John Doe refuses to return back to his home state because he opines that being in New Delhi is much better than being in Shillong (his home town in Meghalaya) due to his subject position as a gay man. This contrast between a small town, Shillong, with the Metropolis New Delhi creates a scenario for situating queer subjectivities in the metropolis. This paper will attempt to study this phenomenon in the light of COVID-19 and how the migration to the metros fixated itself against the pandemic. Whereas reverse migration takes place due to economic and health insecurity, queer migrants from Shillong prefer to stay at the metro for one simple reason that the non-queer migrants didn't have to go through- their sexuality.

(C) AesthetixMS 2020. This Open Access article is published under a Creative Commons Attribution Non-Commercial 4.o International License (http://creativecommons.org/licenses/by-nc/4.o/), which permits non-commercial re-use, distribution, and reproduction in any medium, provided the original work is properly cited. For citation use the DOI. For commercial re-use, please contact editor@rupkatha.com. 
Queer sexuality is a non-normative sexuality which poses a problem toward the construction of state/cultural subjects as in interrogates the stability of the structures through which power apparatus propagates itself(Lamble,2013). As such queer sexuality serves an important role of exposing bare the superficiality of the structures that hold the narrative of state/cultural power together because, on one hand, the cultural patriarchy which forms a center through which power is held, propagated and appropriated is being disturbed and on the other hand, it points that the state continued existence through perpetuating certain citizen selfhood is exclusive. Therefore, and in as much as traditional power structure finds it emetic, queer sexuality will always continue to be at odds with the very apparatuses that had become the very sources for the subjugation and marginalization of queer subjectivities. Because it is always found to be problematic to those cultural structures that create a coherent and homogenous identity, queer sexuality is bound to be shunned at, ridiculed, jeered, marginalized, prosecuted and punished. In this context then, Shillong queer sexualities can be read along with the ongoing reverse migration. Shillong is the capital of Meghalaya.

Against the culture of silence and sexual non-acknowledgement, it is conceivable that queer people would seek to migrate to a better place (and "better" here is a relative term) where they could practice their sexuality in freedom. Now one way to examine this relative freedom is to view it against sexual behavior that the queer people practiced at their hometown and by that I do not imply that the notion of spatiality of sexual behavior holds true. However, what is implicated by the notion of sexual freedom is that quite unique to the North Eastern towns and villages. The term "Northeast" is itself a problematic term when refers to anything outside the contiguous zone of geographical spatiality as the term is pregnant with homogeneity and the causality as such. However nothing is much further from the truth than the idea of Northeastern region of India as a single narrative of a homogenous continuum that categorized the idea of the "Northeast" because the region is one of the most diverse region in India and as such the multitudinality of cultural ethos would render any paradigmatic representation of the region as problematic since the multifarious existence of the culturescape in the region will always results in a reverse gestalt for any theoretical formulation and conceptualization that attempts to fit the region within a single contingency. Keeping this in mind, this paper focus on the state of Meghalaya and its queer sexualities as the author feels that including more than one state within the theoretical framework would jeopardize the twin problem of theoretical representation and theoretical analysis. The problem of sexualities then is not only geographical but also cultural and as such it is important to understand the specific cultural context in which sexuality is formed, sanctioned, regulated, repressed, suppressed and oppressed. Keeping this in mind, this essay attempts to localize its field of study within the context of Khasi-Jaintia people of Meghalaya.

Understanding the Geo-cultural specificity of the Khasis is important in conceptualizing the problem of sexuality in general and the closet in particular because the sanctioning of sexuality, in a way whereby only such sexuality is permissible and in what context, is very important in constructing the reality of any culture as it is a way through which society super structure are maintained through power dynamics and sexuality inherently mimic the normative power dynamics(Foucault,1976 ; Butler,1993). As such, the Khasi society is itself conceived out of the pervasiveness of heteronormativity and the masculine culture. Sociality is a very important aspect of the culture and within a specific in-group (village, locality, church) it is the prevailing 
bond that holds the communal members together. The immediacy and intermediacy of contacts through which the members of the community express and acknowledge their social belonging, while proving to be a great tool in communal well-being, is also detrimental to the construction of alternate sexualities (Halberstam, 2005). As such within a particular in-group/ subgroup, knowledge about the member is pervasive and upon juxtaposing that with the repression of alternate sexuality, it is almost conceivable that the "closet" will impose itself prominently among queer people. This relative absence of anonymity rendered the expression of sexuality difficult if not impossible (Davidson and Pavel, 2018).

My theory, however, is that while heterosexuality is generally suppressed by the societal ethos, and this should not be confused with being oppressed or repressed but simply that one cannot talk about sex, homosexuality and queer sexualities in general are repressed. They belong to the realm of the unconscious and only occasionally manifest themselves through certain cultural tropes. Queer sexuality then remains unacknowledged and its existence is being denied. This repression and denial of the existence of another dimension of sexual reality contribute to the migration from the small town to the metros. The city with its lack of communal social bond that is prevalent in the rural and small-town area offers a new dimension which the queer sexualities could locate themselves. This location of sexuality is equivalent to queer spaces whereby certain mode of queer socialization could take place. Queer socialization is very important in imbibing a certain sense of freedom to the queer community as it relates to the idea of authenticity of communication and expression. It only results in likeminded people bonded together by a sense of belonging created by the same discord of sexuality (Issay, 1986). Queer socialization doesn't not equate with cruising place ( which have lost relevance among queer community due to the advent of online dating sites such as Grindr and Planet Romeo) but with certain spaces whereby queer people could form their own identity, and identity is really a problematic term as such, and imbibes them with a sense of "Being". As such, queer socialization is a characterization of a city where small towns and villages lack. However another characterization of the city is that it tends to give visibility to the queer people while at the same time renders them with anonymity. This paradoxical equation is very important in understanding the culture of silence (and homophobia) which operates in the small towns and villages.

One interesting fact about the Khasi language that is connotative of the situation of queer people is the lack of a particular indigenous vocabulary to describe queer sexuality. Unlike the hijras, kothi,aravani, etc, the Khasi language couldn't describe alternate sexuality and this, in my conclusion, is indicative of the silence and secrecy that queer sexuality has to undergo. The culture does not recognize it and refused to signify it within its larger order. As such, queer sexuality can only gesture through silence (Kosofsky, 1990). By this culture of silence I imply that homosexuality is not erased or oppressed but rather submitted into silence by the cultural refusal to acknowledge its presence. The most important index of this culture of silence is the lack of a linguistic concept to denote its existence and that lack of a word to describe queer sexuality is a major index of this culture of silence in the Khasi society. This is indicative that for centuries, the Khasi community doesn't acknowledge the presence of alternate sexuality as it is being repressed and cannot express itself. That is not to say that there are no homosexual acts among the people, which does seems like an absurd reaction from a retrogressive postcolonialist, but that such acts are not acknowledge that they even exist and that the entire realm of the society acts as one big 
"closet" . However modern users of Khasi language start using words such as "hijra”, "Gay", "Homo", to describe alternate sexualities. These loan words are indicative of the fact that people start acknowledging the existence of alternate sexualities. However, the proliferation of these loan words into the traditional Khasi speaking vocabulary is not positive in its aspect because these words, just as they were employed in English and Hindustani context, are pejorative in nature and used derogatorily. Evidently, the outcome of such speech-acts therefore has an alienating aspect to the queer people. Migration then could play a better outcome for the queer people in their quest for acceptance, tolerance, visibility, dignity and affections. Eithne Luibhéid opines that "Traditionally, studies of immigration have been framed by a view of migrants as individual actors making rational choices based on cost-benefit analysis, the horizon of the nation-state, and the models of assimilation" (2005, p xxi).She, however implies that later scholarship have upend this belief that immigration is affected by cost-benefit analysis (see Sassen,1996). Analyzing the queer migration scholarship, she opines that a lot of those scholarship focus on the dynamics of "the quest for freedom" as the dominant push-pull factor of immigration (2005, p xxv). However, this approach is problematic because of its paradigm is minimalistic. Queer migrants migrated not only as sexed object but "also as racialized, classes, gendered subjects of particular regions and nations..." (xxvi). Luibhéid's theory is in the context of international migration to the United States but what if we are to apply the various variables of migration that she theorized within the context of Khasis queer migration to the metros? What if the quest for freedom is just one of the many variables and that the particular "freedom" associated with the city in the mainland, is only implicative of the lack of freedom in the periphery caused by the equation of conflict that has come to characterize the Northeastern Region as a whole.

Unemployment has been one of the push-factors in immigration. One informant said that "there's no job at home. And I need livelihood. I know a lot of people who got a job at our state, but I also need something more" (Blah,Personal communications, 2020). Another informant is more forthcoming opining, "Shillong is a small place. Everyone knows everyone. In the city, no one knows us personally. We are invisible but that invisibility gives us the freedom to do whatever we want" (Fernandez, Personal Communications, 2020). Fernandez's implicative statement is connotative of the fact that privacy is a great issue in small town and that should not be confused with the fact that privacy doesn't exist at all which it does but because the region itself is intricately linked to heteronormativity, it becomes impossible for someone to come out and is constantly always in a state of concern that someone might outed him because of the personal proximation that people shared with each other. The city, however, acts as a barrier to that personal proximation and one doesn't have to be afraid of being outed. This is a contentious issue ever since Kosofsky theorized that the process of coming out is multifarious and almost unending (1990); however if one is to assume that home is symptomatic of the closet, then there is a possibility (and in fact a very important way of reading any space) that the closet is as much metaphorical as it is spatial- that an entire geographical makeup can be one big closet that someone hides and needs to come out of. In trying to come out of a spatial closet, one is actually moving away from the closet; one is in the process of leaving the closet. This phenomenon of leaving the closet implies that one doesn't let know of one's sexuality but rather one simply moves out of the closet and makes it irrelevance. Looking at Shillong from this perspective of a spatial closet, it is conceivable that those who have managed to leave the closet will never choose to be back inside it. 
Another informant opines that "the pandemic is not really as bad as it is portrayed. It is all paranoia and obsession. In all likelihood, I think I have the virus but I don't really care. Yes now I am jobless but if I go back home, I might never return here. The environment there is not really conducive for queer people. I mean I could have plenty of sex but that's it. There is no queer life or queer environment there" (Pariat, Personal communications, 2020). Another informant opines that he doesn't have any particular reason for not going home but rather he is used to Kolkata. On how the virus affects his life, he opines "I just want to get the virus and served my turn. This status of waiting is quite depressing" (Syngkli, Personal communications, 2020). The informants' attitude about the virus is very interesting. One way why the virus is feared and dreaded is because it has high mortality among the old people. So if one is infected with the virus, he may be asymptomatic but he could pass on the virus to his diabetic mother or his ailing grandmother and that could complicate one's attitude about the virus. It is not merely the concern about personal safety but rather of the family members that also plays a significant role in the response to the pandemic. The informants, however live far away from home, are young and doesn't have comorbidities (Freddie informed me that he is HIV+ but that he is on medication and his viral load is undetectable). The totalizing effect of the family, and by that I mean the family's ability to direct the actions of its member firmly within its fold and within the hetero-familial-norm, is absence in their case (and their refusal to go back home could be read as an attempt to escape from this totalizing effect of the family). In their case, the family is absence and this absence of the family gives them a semblance of freedom not only in their queer life but even in their response to the pandemic

An important symbol that is associative with the pandemic which is pertinent in our understanding of the pandemic is home. Home as a location of preventive containment of the general population is a significant concept in the pandemic. Hence, the lockdown and the immobility imposed upon the population are inherently tied to the idea of home and space. Home-bound queer subjectivities focus on the disruption of the everyday which essentialized their queer identities because the everyday is primal in shaping queer selves (Manalansan, 2005, p 148). Freedie told me that the whole idea of not going to work, not having to stand into the mirror to gaze upon his own reflection can be both debilitating and empowering- on one hand, the everyday that he is so used to that characterized him and sets him apart is no more, uncertain of when it will return back; on the other hand, the whole fact that this could be his new normal affords him a new reality to look up to and to negotiate. He told me, " no more going to the bars to check out guys; no more late night parties' no more unwanted eyes in the street. It's just me, my room and my phone. My queerness exhibit itself only through casual phone sex, if I even feel the need to do so which is so rare" (Freedie. Personal communication, 2020). I asked him "wouldn't you also get the do the same at home?" to which he replies, "yes but at home I live in a two bedroom house. I share the room with my younger brother. And our house is pretty porous to conversation. Out here, its my own world, small but my own." (Freedie, Personal communications, 2020). So the very basic structure of homeliness is anathema to the expression of queerness and queer intimacy. David Eng opines that the parameters such as home, intimacy, privacy, are important location of understanding queer subject (1997, p 31-52). Therefore, migrants and diaspora create a new order of homeliness which Gilroy termed as diasporic intimacy (1993, p 16). Manalansan describes this term as what constitutes " these struggles that showcase the different ways in which the state, public life and the world outside intrude on and permeate these 
seemingly bounded, private, and domestic spaces of home and how diasporic subjects confront them "(2005,p148). If we use this concept and applies it to the queer intimacy of the northeastern region, we could deconstruct homeliness and its relation toward the formation of Northeast queer subjectivities in the mainland India.

The homeliness of home posits that there exists a relationship by which domesticity, privacy, and intimacy affects the formation of fixed identities through which one could locate the locus of his existence (Berlant, 1998, p 287). A home enables interplay between these three parameters, allowing them to create a semblance of order and belonging among the subjectivities. However, the situational reality of Shillong is not conducive toward the formation of queer subjectivities- one being the interplay between privacy and intimacy is disrupted by the personal and communal proximation characterized of a small town; second being the neat equilibrium between domesticity and intimacy is altogether severed when there in a non-normative intimacy as the domestic would intrude into the realm of the private. As such queer people like Freedie don't feel the need to go back home even during the pandemic as it would create a new readjustment in their life since it would mean that a new mode of interplay has to be recalibrated. These variables of privacy, domesticity and intimacy would have to create a new ecosystem of existence if they are to accommodate queer subjectivities; however, given how these variables are also intricately link with the other external factors that are paramount in the establishment of societal and cultural super structures, it would be almost useless for them to readjust and recalibrate. As such, home is futile is allowing the formation of queer subjectivities. Home as such indicates both the familial home and Shillong itself. Returning back to this home would mean a start over both in re-affirming sexualities and even in negotiating the everyday which is different from the everyday of the metropolis. This is what Freedie meant when he exclaims, "There is no home, pig”. Freedie categorically denied the notion of home among queer people. Judith Halberstam in asking to 'forget the family' opines:

Queer intervention into kinship studies have taken many forms: some call for new model of family (Butler's Antigone as a substitute for Oedipus, Weston's chosen families as a substitute for a blood bond); others call for a recognition of friendship ties as kinship; and still other scholars ask that we recognize the difference that gay and lesbian parents make to the very meaning of family. But few scholars call for an emphasis on family or a rejection of the family altogether (2007, p 317).

The act of "forgetting the family' is not equivalent with abandoning the family altogether. While one may, for a time being, postpone the process of acknowledging the intimacy of the family, one always conscious that the family is ever be and always there. However, when a dichotomy between a family and a home is deliberately inserted into the discourse, the latter occupies a more ambiguous locus whereby it can be rejected altogether since its physicality is as much important as its psychological aspect. Therefore, one can leave home, come out, come back and reject it. In the city, a particular apartment of the queer people become queerised and it forms a fundamental part of queer space which is a radical alternative to heterosexual space (Oswin , 2008). Back in Shillong, a home is simply a home and not a queer space but in the city, it is necessary in the 
formation of sexual identities through the relationship between "self-identification and built environment" (Lashkari 3). Harvey (2003), Shaw and Hudson (2009), Nash (2011), have opines that the production of sexed bodies and the understanding of sexuality is tied to space.

The pandemic plays an important role in affirming queer citizenship which is also one of the main reasons for the refusal of these queer subjectivities to leave the city despite the danger. Arbedeen opines that the pandemic has very much disturbs the notion of what is meant to be queer. " waiting at home all day, not sure if you're going to live or die, not sure if you are a sexed being anymore is very debilitating" (Arbedeen, Personal communications, 2020). However Aberdeen also opines that while they were always perceived as ultra-sexual subjectivities, which is associative of queer interlinkage with promiscuity (Rao, 2016; Dean 2006, Dollimore, 1991), the pandemic has, in a way, changed the very perception of queerness. The lockdown enabled the discourse on sex to be, for a while, postponed from the definitive categorisation of queer and sexuality itself. As such, to be queer, contrary to what queer theorists have posited that it is a position outside identity (Edelman, 2004) assumes a definite position of identification. As such, the pandemic and the lockdown affirm subjectivities in the queer subject by enabling them to identify with that position of being queer despite the fact that the very mode of queerity in unavailable to them.

The information provides by these seven queer men from Shillong serves as a case study in understanding the effect of the pandemic and the subsequent lockdown upon queer subjectivities. The pandemic has enabled them to critique the very idea of going home and of the idea of home itself. The home is not a stable, all-encompassing place but rather it shares a much more complex relation with the queer subjects. First, it exists within a larger backdrop which in turn directs its response to queer subjectivities; and secondly, home itself is not a stable positionality and as such can be appropriated elsewhere. In doing so, these queer subjects create a new home for themselves, a space which they have queerified. Furthermore, the pandemic while posing difficulties to the life and livelihood of the queer subjects, it shifts the discourse on queerity to a new topography and as such it has its own unique way of affirming queer as a position of identification (in the least). Although they face difficulties, since the human body is vulnerable to disease, their position as queer subjects prevents them from going back to the same place that they try to come out of. In as much as queer anti-urbanism tries to make a case for rural queerness (Herring2, o10; Staple, 2010; Budd, 2011), for these queer subjects, metronormativity is the only norm that they are willing to appropriate.

\section{References}

Berlant, Lauren. (1998). Intimacy: A special issue. Critical Inquiry 24(2)

Bhagat,R.S., Reshmi RS, Harihar Rao, Archana K Roy \& Dipti Govil (2020). The COVID 19, Migration and Livelihood in India. IIPS Analytical Series on COVID 19. IIPS.

Budd, Jerke. (2011). Queer ruralism. Harvard Journal of Law and Gender34.260-312. Butler, Judith.(1993).Bodies that matter: On the discursive limits of sex. Routledge. 
David, Eng (1997). Out here and over there: Queerness and diaspora in Asian-American Studies. Social Text 52-53, 31-52.

Davidson, K and Pavel, Sagolsem. (March 19,2018). Do queer migrants from The Northeast find Indian cities alienating or empowering? Plainspeak: A digital magazine onsexuality in the global south,Tarshi. www.tarshi.net/inplainspeak/queer-migrants-northeast-find-indian-cities -alienating-empowering/. Accessed on 10, October 2019.

Dean, Tim. (2006). Beyond Sexualities. Routledge.

Dollimore, Jonathan. (1991). Sexual dissidence: Agustine to Wilde, Freud to Foucault. ClaredonPress.

Edelman, Lee. (2004). No Future: Queer theory and the death drive. Duke University Press.

Eithne Luibhéid (2005). Introduction. In Eithne Luibhéid and Lionel Cantu Jr (Eds)Queer Migrations: Sexuality. U.S. citizenship and bordercrossing, (pp ix-xliv). University of Minnesota Press.

Foucault, Michel. (1976). The History of sexuality: The will to knowledge. Penguin UK.

Gilroy, Paul (1993). The black Atlantic: Modernity and double consciousness. Cambridge University Press.

Halberstam, J(2007a).. Forgetting family: Queer alternatives to oedipal relations. In G.E. Haggerty and M. McGarry(Eds)A Companion to LGBTQ Studies,(pp 315-24), Blackwell.

Halberstam, J (2005b). In A queer time and place: Transgender bodies, subcultural lives. New York University Press.

Harvey, D (2003). The Right to the city. International Journal of Urban and Regional Research27(4),pp 939941

Herring, Scott. 2007. Out of the closets. Into the woods: RFD country women, and the post-Stonewall emergence of queer anti-urbanism. American Quaterly,59(2), 341-372. Doi:10.1353/aq.2007.0043.

Issay, Richars A. (1986). The Development of sexual identity in homosexual men. The Psychoanalytic study of the child 41(1),467-489. DOI: 10.1080/00797308.1986.11823469

Kosofsky, Eve Sedgwick. (1990). Epistemology of the Closet. Routledge.

Lamble, Sarah. 2013. Queer necropolitics and the expanding carceral state: Interrogating sexual investment in punishment. Law and Critique.24(3). Doi: 10.1007/s10978-013-9125-1

Lashkari, Maryam. (2018). Queer space: Inclusive or exclusive?: A Comparative study of two public spaces in Tehran and Madrid. (MA Dissertation, Vrije Universiteit Brussel). 4CITIES, Master in Urban Studies.

Manalansan IV, Martin F (2005). Migrancy, modernity, mobility: Quotidian struggles and queer diasporic intimacy. In Eithne Luibhéid and Lionel Cantu Jr (Eds)Queer migrations: Sexuality. U.S. citizenship and bordercrossing, (pp. 146-160). University of Minnesota Press.

Nash, C.J. 2011. Trans experiences in lesbian and queer space. The Canadian Geographer. 55(2),pp. 192-207.

Oswin, Natalie (2008). Critical Geographies and the uses of sexuality: deconstructing queer space. Progress in Human Geographies, 32(1), 89-103. DOI: 10.1177/0309132507085213

Rao, Raj (2017). Criminal love? Queer theory, culture, and politics in India. Sage.

Shaw, P \& Hudson, J. (2009). Qualities of informal space: (Re)Appropriation within the informal, interstitial spaces of the city. Occupation: Negotiations with Constructed Space. University of Brighton.

Staple. Christopher. (2010). Reclaiming rural ruralities: (Anti)metronormativity (De)colonization of rural space and place. American Sociological Association Annual Meeting, Hilton Atlanta and Atlanta Marriot Marquis. 